\title{
PERIODONTO BŪKLE் ORTODONTIŠKAI GYDANT KAPOMIS IR FIKSUOTA BREKETŲ SISTEMA
}

\author{
Kristė Labutytè \\ Vilniaus universiteto Medicinos fakultetas, Odontologijos institutas
}

Raktažodžiai: periodonto būklè, ortodontinis gydymas, kapos, breketai.

\begin{abstract}
Santrauka
Ortodontinis gydymas fiksuota breketų sistema sunkina pacientų individualios burnos higienos galimybes, todèl skatinamas podanteninio apnašo kaupimasis, didinantis periodonto ligų išsivystymo riziką. Prieš du dešimtmečius buvo pasiūlyta ortodontinio gydymo fiksuota breketų sistema alternatyva - gydymas skaidriomis išimamomis kapomis. Šis metodas ịgalina pacientą efektyviau atlikti individualią burnos higieną, tačiau skaidrios kapos didžiąją paros dalị dengia visą danties vainiko paviršių bei dalị kraštinių dantenų, todèl gali prastinti periodonto būklę. Tyrimo tikslas - išanalizuoti ir palyginti kapomis ir fiksuota breketų sistema gydomų pacientų periodonto būklę. Mokslinių straipsnių paieška atlikta Pubmed (Medline), Cochrane ir Science Direct duomenų bazèse. Šioje apžvalgoje išanalizuoti 6 viso teksto moksliniai straipsniai, atitikę atrankos kriterijus. Straipsnių analizès rezultatų duomenimis, nèra bendrosios nuomonès, jog kapomis gydomų pacientu periodonto būklè būtų geresné, nei taikant ortodontini gydymą fiksuota breketų sistema. Kapomis gydomų pacientų periodonto būklè yra geresnè, nei gydant fiksuota breketų sistema, arba skirtumo tarp šiomis sistemomis gydomų pacientų nestebima, tačiau patikimesnèms išvadoms reikalingos tolesnès, ilgesnio stebejjimo periodo bei didesnès apimties studijos.
\end{abstract}

\section{İvadas}

Dantų apnašas laikomas pagrindiniu periodonto ligų etiologiniu veiksniu [1]. I dantų apnaše esančių bakterijų medžiagų apykaitos produktus ir patogeniškus toksinus dantenos reaguoja uždegiminiu atsaku - išsivysto gingivitas. Apnašui kaupiantis, jame didèja periodonto audiniams patogeniškų mikroorganizmų kiekis, inicijuojami uždegimą skatinančių citokinų gamybos procesai [2]. Nors gingivitas ne visada progresuoja ị periodontitą, tačiau prieš išsivystant periodontitui, visuomet stebimas dantenų uždegimas $[3,4]$.

Esant netaisyklingam sąkandžiui, dažnai pasirenkamas ortodontinis gydymas fiksuota breketų sistema, ypač tuomet, kai gydomi vaikai ir paaugliai [5]. Nors šis ortodontinio gydymo metodas efektyvus gydant įvairias sąkandžio patologijas, tačiau jis sunkina pacientų individualios burnos higienos galimybes [6]. Sunkiai pasiekiamose vietose kaupiasi dantų apnašas, todèl ortodontiškai gydomiems pacientams dideja èduonies, gingivito ir periodontito išsivystymo rizika $[6,7]$. Tyrimų duomenimis, gydymas fiksuota breketų sistema skatina podanteninio apnašo kaupimąsi, kuriame vyrauja periodonto audiniams patogeniškos Porphyromonas gingivalis, Prevotella intermedia, Bacteroides forsythus, Actinobacillus actinomycetemcomitans, Fusobacterium nucleatum ir Treponema denticola bakterijų padermès [8-10]. Kaupiantis dantų apnašui, iš pradžių dantenų uždegiminis atsakas pasireiškia dantenų kraujavimu, dantenų padidejjimu, padidèja kišenès zondavimo gylis, tačiau nestebimas periodonto jungties praradimas [11]. Ligai progresuojant, galimas sunkesnio laipsnio periodonto audinių pažeidimas ir periodontito išsivystymas [12]. Tyrimų duomenimis, ligatūriniais ir neligatūriniais breketais gydomų pacientų periodonto būklè gali skirtis dèl šių sistemų skirtingų fizinių ir klinikinių savybių [13].

Prieš du dešimtmečius buvo pasiūlyta ortodontinio gydymo fiksuota breketų sistema alternatyva - gydymas skaidriomis išimamomis kapomis [5]. Kapos yra priimtinesnès pacientui dèl geresnio estetinio vaizdo, palengvinama burnos priežiūra ortodontinio gydymo metu, pacientui sukeliama mažiau diskomforto [14]. Jos gali būti išimamos valgant, geriant, atliekant burnos higieną, todèl dantų apnašas gali būti efektyviai pašalinamas, sumažinant èduonies bei periodonto ligų riziką $[15,16]$. Didžiają paros dalį skaidrios kapos dengia visą paciento danties vainiko paviršių bei dalị kraštinių dantenų, todèl tai gali prastinti periodonto būklę [16]. Aktualu išsiaiškinti, ar skiriasi pacientų periodonto būklè gydant fiksuota breketų sistema ir skaidriomis kapomis, palyginti tyrimų rezultatus ir pateikti ịrodymais pagrịstas išvadas. 
Tyrimo tikslas - išanalizuoti ir palyginti kapomis ir fiksuota breketų sistema gydomų pacientų periodonto būklę.

\section{Medžiaga ir metodai}

Atlikta mokslinès literatūros apžvalga ir analizè. Mokslinių straipsnių paieška atlikta Pubmed (Medline), Cochrane Libray ir Science Direct duomenų bazėse. Duomenų paieška buvo vykdoma 2021 metų kovo - balandžio mènesiais. Tyrimo metu atrinkti viso teksto moksliniai straipsniai, kurių pavadinimas, santrauka ir raktažodžiai bei jų junginiai nurodè tinkamumą atliekamai apžvalgai. Mokslinès publikacijos atrinktos pagal nustatytus straipsnių įtraukimo ir atmetimo kriterijus (1 lentelè). Paieškoje naudoti raktažodžiai: periodontal health, clear aligners, fixed orthodontic appliances, dental plaque, gingival health.

\section{Tyrimo rezultatai}

Tyrimo metu buvo atrinkti 6 viso teksto moksliniai straipsniai, atitikę atrankos kriterijus [5,13,17-20]. Mokslinių straipsnių analizès rezultatai pateikti 2 lentelèje.

Remiantis išanalizuotų mokslinių tyrimų duomenimis, nèra bendrosios nuomonès, jog kapomis gydomų pacientu periodonto būklè būtų geresnè, nei taikant ortodontinį gydymą fiksuota breketų sistema. A. Madariaga (2020), A. Chhibber (2018) ir bendraautorių tyrimuose nustatyta, kad kapomis gydomų pacientų periodonto būklè nèra statistiškai reikšmingai geresnè, lyginant su ligatūriniais ir neligatūriniais breketais gydomų pacientų periodonto būkle $[17,18]$. F. Mulla Issa ir bendraautorių tyrime nustatyta, kad kapomis gydomų pacientų periodonto būklè yra geresnè nei tiriamųjų, gydomų ligatūriniais breketais [13]. Šiame tyrime nepastebeta statistiškai reikšmingų skirtumų tarp kapomis ir neligatūriniais breketais gydomų pacientų periodonto būklès. L. Levrini (2015), A. Azaripour (2015), M. Karkhanechi (2013) ir bendraautorių tyrimų rezultatai parodè, kad kapomis gydomų pacientų periodonto būklè statistiškai reikšmingai geresnè, lyginant su tiriamaisiais, gydomais fiksuota breketų sistema (2 lentelè) $[5,19,20]$.

\section{Diskusija}

Taikant ortodontini gydymą kapomis, stebimas sumažèjęs dantų apnašų kiekis dèl geresnių sąlygų individualiai burnos higienai, nei gydant fiksuota breketų sistema, todèl mažesnè periodonto ligų rizika $[13,19]$. F. Mulla Issa (2020), M. Karkhanechi (2013) ir bendraautorių tyrimai parodè, kad dantenų ir apnašų indeksai reikšmingai mažesni kapomis gydytų pacientų grupeje, lyginant su ligatūriniais breketais gydytais tiriamaisiais $[13,20]$. A. Azaripour ir bendraautorių tyrimo rezultatų duomenimis, vagelès kraujavimo ir dantenų indeksų reikšmès mažesnès kapomis gydytų pacientų grupeje, lyginant su fiksuota breketų sistema gydyta pacientų grupe [5]. L. Levrini ir bendraautoriai pateikia išvadą, kad periodonto būklè yra geresnè gydant kapomis, nei fiksuota breketų sistema, kadangi atlikto tyrimo metu nustatytos reikšmingai geresnès tirtų indeksų ir kitų vertinimo kriterijų reikšmès [19]. R. Miethke ir S. Vogt bei R. R. Miethke ir K. Brauner tyrimų rezultatai taip pat rodo, jog dantų apnašų indeksas ortodontinio gydymo kapomis metu yra mažesnis, nei gydant fiksuota breketų sistema [15,16]. G. Rossini (2015) ir bendraautorių sisteminejje apžvalgoje pateikiama išvada, jog periodonto būklè geresnè pacientus gydant kapomis, nei fiksuota breketų sistema, tačiau pabrèžiama, jog analizuoti tyrimai turi metodologinių trūkumų [21].

A. Chhibber, A. Madariaga ir bendraautoriu tyrimų rezultatai prieštarauja vyraujančiai nuomonei, jog išimamos kapos nedaro jokio ar turi tik nedidelị neigiamą poveikị periodonto būklei $[5,16-18,20]$. Šių tyrimų rezultatai nesutampa su jau aptartų, i analizę įtrauktų L. Levrini, A. Azaripour, M. Karkhanechi ir bendraautorių tyrimų rezultatais $[17,18]$. A. Chhibber, A. Madariaga ir bendraautorių tyrimu duomenimis, periodonto būklè nesiskiria tarp kapomis ir fiksuota breketų sistema gydomų pacientų grupių. Kapos uždengia visą danties paviršių bei 1-2 mm kraštinių dantenų, todèl sumažèja ant danties paviršiaus patenkančių seilių kiekis [22]. Nepakankamas seilių kiekis ant danties paviršiaus ortodontinio gydymo kapomis metu mažina savaiminio burnos apsivalymo efektyvumą, todèl galimas potencialiai didesnis dantų apnašo kaupimasis [23]. Itakos prastesnei periodonto audinių būklei gali turetti ir tai, jog išimamų kapų kraštas dažnai nèra visiškai tolygus, todèl

1 lentelè. Mokslinių straipsnių atrankos kriterijai.

\begin{tabular}{|l|l|}
\hline $\begin{array}{l}\text { Itraukimo ị tyrimą kri- } \\
\text { terijai }\end{array}$ & \multicolumn{1}{|c|}{ Atmetimo kriterijai } \\
\hline $\begin{array}{l}\text { Tyrime lyginama perio- } \\
\text { donto būklè gydant ka- } \\
\text { pomis ir fiksuota breketų } \\
\text { sistema }\end{array}$ & Metaanalizė \\
\hline $\begin{array}{l}\text { Tyrimai, atlikti su žmonè- } \\
\text { mis }\end{array}$ & $\begin{array}{l}\text { Tyrimai, atlikti su néščiosiomis ar } \\
\text { tiriamaisiais, turinčiais genetinių } \\
\text { sindromų }\end{array}$ \\
\hline $\begin{array}{l}\text { Ne senesni nei } 10 \text { metų } \\
\text { tyrimai }\end{array}$ & $\begin{array}{l}\text { Tyrimo dalyviai vartoja vaistus, tu- } \\
\text { rinčius įtakos dantenų būklei }\end{array}$ \\
\hline $\begin{array}{l}\text { Tyrimai aprašyti anglų } \\
\text { kalba }\end{array}$ & $\begin{array}{l}\text { Tyrimo dalyviai, nešiojantys dalinius } \\
\text { išimamus protezus }\end{array}$ \\
\hline $\begin{array}{l}\text { Atliktas klinikinis perio- } \\
\text { donto audinių ištyrimas }\end{array}$ & Literatūros apžvalga \\
\hline $\begin{array}{l}\text { Tyrimo dalyviai neserga } \\
\text { periodontitu, sisteminėmis } \\
\text { ligomis, nerūko }\end{array}$ & Senesni nei 10 metų tyrimai \\
\cline { 2 - 3 } & Atvejo aprašymas \\
\cline { 2 - 2 } & Santrauka \\
\hline
\end{tabular}


2 lentelè. Mokslinių straipsnių analizès rezultatai [5,13,17-20].

\begin{tabular}{|c|c|c|c|c|c|}
\hline $\begin{array}{l}\text { Autoriai, } \\
\text { tyrimo metai }\end{array}$ & $\begin{array}{l}\text { Tyrimo tipas, } \\
\text { imtis }\end{array}$ & $\begin{array}{l}\text { Tiriamụjų } \\
\text { vidutinis } \\
\text { amžius, m. }\end{array}$ & $\begin{array}{l}\text { Ortodontinis prietaisas ir } \\
\text { periodonto būklès ịverti- } \\
\quad \text { nimo laikas }\end{array}$ & Vertinimo kriterijai & Rezultatai \\
\hline \multirow[t]{3}{*}{$\begin{array}{l}\text { Madariaga } \\
\text { ACP ir kt., } \\
2020[17]\end{array}$} & $\begin{array}{l}\text { Perspektyvusis, } \\
\mathbf{n}=\mathbf{4 0}\end{array}$ & & $\begin{array}{l}\text { Vertinimas prieš ortodontini } \\
\text { gydymą (T0) ir } 3 \text { mèn. po } \\
\text { gydymo (T1) }\end{array}$ & \multirow[t]{3}{*}{$\begin{array}{l}\text { Apnašų indeksas, krau- } \\
\text { javimas po zondavimo, } \\
\text { dantenų recesija }\end{array}$} & \multirow[t]{3}{*}{$\begin{array}{l}\text { Fiksuota breketų sistema ir kapomis } \\
\text { gydomų pacientų periodonto būklè sta- } \\
\text { tistiškai reikšmingai nesiskyrė }\end{array}$} \\
\hline & 1 grupè $(n=20)$ & $20,6 \pm 8,1$ & Ligatūriniai breketai & & \\
\hline & 2 grupè $(n=20)$ & $34,7 \pm 12,5$ & Kapos & & \\
\hline \multirow[t]{5}{*}{$\begin{array}{l}\text { Mulla Issa } \\
\text { FHK ir kt., } \\
2020[13]\end{array}$} & $\begin{array}{l}\text { Skerspjūvio, } \\
\mathbf{n = 8 0}\end{array}$ & & $\begin{array}{l}\text { Vertinimas po } 6 \text { mèn. nuo } \\
\text { gydymo pradžios }\end{array}$ & \multirow{5}{*}{$\begin{array}{l}\text { Vertinti } 7 \text { indeksai: } \\
\text { apnašų, dantenų, dan- } \\
\text { tenų kraujavimo, vage- } \\
\text { lès kraujavimo, papilos } \\
\text { kraujavimo, periodonto } \\
\text { ištyrimo ir kraujavimo po } \\
\text { zondavimo }\end{array}$} & \multirow{5}{*}{$\begin{array}{l}\text { Periodonto būklè tarp beligatūriniais } \\
\text { breketais ir kapomis gydytų pacientu } \\
\text { reikšmingai nesiskyrè. Periodonto bū- } \\
\text { klè reikšmingai geresnè gydant kapomis } \\
\text { lyginant su ligatūriniais breketais gydyta } \\
\text { pacientų grupe }\end{array}$} \\
\hline & 1 grupe $(n=20)$ & $26,65 \pm 5,15$ & $\begin{array}{l}\text { Metaliniai ligatūriniai bre- } \\
\text { ketai }\end{array}$ & & \\
\hline & 2 grupe $(n=20)$ & $27,65 \pm 8,15$ & Keraminiai breketai & & \\
\hline & 3 grupè $(n=20)$ & $26,85 \pm 5,19$ & Neligatūriniai breketai & & \\
\hline & 4 grupè $(n=20)$ & $26,85 \pm 4,83$ & Kapos & & \\
\hline \multirow[t]{4}{*}{$\begin{array}{l}\text { Chhibber A. ir } \\
\text { kt., } 2018 \text { [18] }\end{array}$} & $\begin{array}{l}\text { Perspektyvusis } \\
\text { atsitiktinių imčių } \\
\mathbf{n = 7 1}\end{array}$ & & $\begin{array}{l}\text { Vertinimas prieš ortodontini } \\
\text { gydymą (T0), po } 9 \text { mèn. nuo } \\
\text { gydymo pradžios (T1), po } 18 \\
\text { mèn. nuo gydymo pradžios } \\
\text { (T2) }\end{array}$ & \multirow[t]{4}{*}{$\begin{array}{l}\text { Apnašų indeksas, papilos } \\
\text { kraujavimo indeksas, dan- } \\
\text { tenų indeksas }\end{array}$} & \multirow{4}{*}{$\begin{array}{l}\text { Tirtų indeksų reikšmės statistiškai reikš- } \\
\text { mingai mažesnès praejus } 9 \text { mėnesiams } \\
\text { nuo gydymo pradžios kapomis gydomų } \\
\text { pacientų grupėje lyginant su ligatūriniais } \\
\text { ir neligatūriniais breketais gydytomis pa- } \\
\text { cientų grupėmis. Po } 18 \text { mėnesių statis- } \\
\text { tiškai reikšmingų skirtumų tarp grupių } \\
\text { nepastebèta }\end{array}$} \\
\hline & 1 grupè $(n=27)$ & $16,56 \pm 3,99$ & Kapos & & \\
\hline & 2 grupè $(n=22)$ & $15,39 \pm 3,54$ & Neligatūriniai breketai & & \\
\hline & 3 grupè $(n=22)$ & $14,56 \pm 3,92$ & Ligatūriniai breketai & & \\
\hline \multirow[t]{4}{*}{$\begin{array}{l}\text { Levrini L. ir } \\
\text { kt., } 2015 \text { [19] }\end{array}$} & $\begin{array}{l}\text { Perspektyvusis } \\
\mathbf{n}=\mathbf{7 7}\end{array}$ & & $\begin{array}{l}\text { Vertinimas prieš ortodontini } \\
\text { gydymą (T0), po } 1 \text { mèn. nuo } \\
\text { gydymo pradžios (T1) ir po } \\
3 \text { mèn. nuo gydymo pradžios } \\
\text { (T2) }\end{array}$ & \multirow[t]{4}{*}{$\begin{array}{l}\text { Apnašų indeksas, krauja- } \\
\text { vimo po zondavimo ịverti- } \\
\text { nimas, kišenių zondavimo } \\
\text { gylis }\end{array}$} & \multirow[t]{4}{*}{$\begin{array}{l}\text { Periodonto būklè statistiškai reikšmingai } \\
\text { geresnè kapomis gydytų pacientų gru- } \\
\text { pẻje, lyginant su fiksuota breketų sistema } \\
\text { gydytų pacientų grupe }\end{array}$} \\
\hline & 1 grupè $(n=32)$ & \multirow{3}{*}{24,3} & Kapos & & \\
\hline & 2 grupè $(n=35)$ & & Ligatūriniai breketai & & \\
\hline & 3 grupè $(n=10)$ & & Kontrolinè, negydyta & & \\
\hline \multirow[t]{3}{*}{$\begin{array}{l}\text { Azaripour A. } \\
\text { ir kt., } 2015 \\
{[5]}\end{array}$} & $\begin{array}{l}\text { Skerspjūvio } \\
\mathbf{n = 1 0 0}\end{array}$ & & & \multirow[t]{3}{*}{$\begin{array}{l}\text { Dantenų indeksas, vagelès } \\
\text { kraujavimo indeksas, mo- } \\
\text { difikuotas apnašų indeksas }\end{array}$} & \multirow{3}{*}{$\begin{array}{l}\text { Vagelès kraujavimo indeksas ir dantenų } \\
\text { uždegimo sunkumo laipsnis statistiškai } \\
\text { reikšmingai mažesnis kapomis gydytų } \\
\text { pacientu grupejje, lyginant su fiksuota } \\
\text { breketų sistema gydyta pacientų grupe }\end{array}$} \\
\hline & 1 grupè $(n=50)$ & $31,9 \pm 13,6$ & $\begin{array}{l}\text { Kapos. Vertinimas prieš } \\
\text { gydymą ir praejus } 12,9 \pm \\
7,2 \text { mèn. nuo gydymo pra- } \\
\text { džios }\end{array}$ & & \\
\hline & 2 grupè $(n=50)$ & $16,3 \pm 6,9$ & $\begin{array}{l}\text { Fiksuota breketu sistema. } \\
\text { Vertinimas prieš gydymą ir } \\
\text { praejus } 12,6 \pm 7,4 \text { mėn. nuo } \\
\text { gydymo pradžios }\end{array}$ & & \\
\hline \multirow[t]{3}{*}{$\begin{array}{l}\text { Karkhane- } \\
\text { chi M. ir kt., } \\
2013[20]\end{array}$} & $\begin{array}{l}\text { Perspektyvusis } \\
\mathbf{n}=\mathbf{4 2}\end{array}$ & & $\begin{array}{l}\text { Vertinimas prieš gydymą, po } \\
6 \text { sav., po } 6 \text { mėn., po } 12 \text { mèn. } \\
\text { nuo gydymo pradžios }\end{array}$ & \multirow[t]{3}{*}{$\begin{array}{l}\text { Apnašų indeksas, dantenų } \\
\text { indeksas, kišenių zonda- } \\
\text { vimo gylio įvertinimas }\end{array}$} & \multirow[t]{3}{*}{$\begin{array}{l}\text { Gydant fiksuota breketų sistema dides- } \\
\text { nės apnašų ir dantenų indeksų reikšmės, } \\
\text { gilesnès zonduojamos kišenès, didesnis } \\
\text { kraujuojančių sričių skaičius nei kapomis } \\
\text { gydytų pacientų grupejje }\end{array}$} \\
\hline & 1 grupè $(n=22)$ & $34 \pm 7,18$ & Ligatūriniai breketai & & \\
\hline & 2 grupè $(n=20)$ & $28 \pm 6,86$ & Kapos & & \\
\hline
\end{tabular}


galimas kraštinių dantenų dirginimas [18].

A. Chhibber ir bendraautorių tyrime statistiškai reikšmingi periodonto būklès skirtumai tarp kapomis ir breketais gydomų pacientų buvo pastebèti praejus 9 mėnesiams nuo ortodontinio gydymo pradžios, tačiau atlikus ištyrimą po 18 mènesių, reikšmingų skirtumų nepastebėta [18]. A. Chhibber ir bendraautoriai rezultatų nesutapimus skirtingais laikotarpiais grindžia keletu priežasčių. Pirmiausia, tiriamiesiems galimai itakos turejjo vadinamasis „Hawthorne“ efektas - psichologinis poveikis, kai tyrimo dalyviai keičia elgesị dẻl to, nes yra stebimi ir analizuojami eksperimento ar tyrimo metu. Tokiu atveju fiksuota breketų sistema gydomi pacientai galejo kruopščiau atlikti individualios burnos higienos procedūras nei ịprastai, todèl breketais gydomų pacientų periodonto būklè buvo tokia pat gera kaip ir tiriamujų, gydomų kapomis. Kita galima priežastis, dèl kurios A. Chhibber ir bendraautorių tyrimo rezultatai skyrèsi praejjus 9 ir 18 mènesių nuo ortodontinio gydymo pradžios - tiriamųų amžius. Vyresnio amžiaus pacientai dažnai labiau linkę bendradarbiauti ir laikytis gydytojo nurodytų individualios burnos higienos instrukcijų [24,25]. Nuo pirmosios patikros praejjus 9 mènesiams, fiksuota breketų sistema gydomi pacientai labiau subrendo, todèl galèjo geriau laikytis individualios burnos higienos instrukcijų ir jų periodonto būklè nesiskyrè nuo pacientų, gydomų fiksuota breketų sistema. A. Chhibber ir bendraautorių tyrimo eigoje 10 asmenų nebuvo ištirti tam tikru tiriamuoju laikotarpiu, todèl tai galejo turèti ịtakos gautu duomenų statistiniam patikimumui.

A. Madariaga ir bendraautoriai pastebejo, jog pacientų, gydomų kapomis ir fiksuota breketų sistema, periodonto būklè reikšmingai nesiskiria [17]. Autorių nuomone, gautiems rezultatams įtakos galèjo turèti tai, jog šio tyrimo dalyviai buvo kviečiami atvykti apžiūrai kas 2 savaites, kiekvieną kartą buvo motyvuojami bei informuojami, kaip tinkamai atlikti individualią burnos higieną. A. Madariaga ir bendraautoriai pateikia išvadą, jog periodonto būklè ortodontinio gydymo kapomis ir fiksuota breketų sistema reikšmingai nesiskiria, jei pacientai yra motyvuojami ir apmokomi tinkamos individualios burnos higienos. Šis tyrimas truko vos 3 mènesius, todèl norint patikimesnių rezultatų, tikslinga atlikti pacientų ịvertinimą praejjus ilgesniam laikui nuo ortodontinio gydymo pradžios.

Siekiant patvirtinti ar paneigti analizuotų tyrimų rezultatus, reikalingos tolesnès, ilgesnio stebejjimo periodo bei didesnès apimties studijos. Patikimesniems duomenims gauti reikalingi ilgesnès trukmės kontroliuojami klinikiniai tyrimai, vertinantys kapomis ir fiksuota breketų sistema gydomų pacientų periodonto būklę.

\section{Išvados}

1. Kapomis gydomų pacientų periodonto būklè yra geresnè, nei gydant fiksuota breketų sistema arba skirtumo tarp šiomis sistemomis gydytų pacientų nenustatyta.

2. Vertinant tyrimų heterogeniškumą, patikimų išvadų pateikti negalima, todèl reikalingi tolesni tyrimai.

\section{Literatūra}

1. Loe H. Physiological aspects of the gingival pocket. An experimental study. Acta Odontol Scand 1961;19:387-95.

https://doi.org/10.3109/00016356109043397

2. Ren Y, Vissink A. Cytokines in crevicular fluid and orthodontic tooth movement. Eur J Oral Sci 2008;116(2):89-97.

https://doi.org/10.1111/j.1600-0722.2007.00511.x

3. Machtei EE, Hausmann E, Dunford R, Grossi S, Ho A, Davis G, et al. Longitudinal study of predictive factors for periodontal disease and tooth loss. J Clin Periodontol 1999;26(6):374-80. https://doi.org/10.1034/j.1600-051X.1999.260607.x

4. Listgarten MA, Schifter CC, Laster L. 3-year longitudinal study of the periodontal status of an adult population with gingivitis. J Clin Periodontol 1985;12(3):225-38. https://doi.org/10.1111/j.1600-051X.1985.tb00920.x

5. Azaripour A, Weusmann J, Mahmoodi B, Peppas D, Gerhold-Ay A, Van Noorden CJF, et al. Braces versus Invisalign ${ }^{\circledR}$ : gingival parameters and patients' satisfaction during treatment: a crosssectional study. BMC Oral Health 2015;15:69.

https://doi.org/10.1186/s12903-015-0060-4

6. Liu H, Sun J, Dong Y, Lu H, Zhou H, Hansen BF, et al. Periodontal health and relative quantity of subgingival porphyromonas gingivalis during orthodontic treatment. Angle Orthod 2011;81(4):609-15.

https://doi.org/10.2319/082310-352.1

7. Bollen A-M, Cunha-Cruz J, Bakko DW, Huang GJ, Hujoel PP. The effects of orthodontic therapy on periodontal health: a systematic review of controlled evidence. J Am Dent Assoc 2008;139(4):413-22.

https://doi.org/10.14219/jada.archive.2008.0184

8. Gomes SC, Varela CC, da Veiga SL, Rösing CK, Oppermann RV. Periodontal conditions in subjects following orthodontic therapy. A preliminary study. Eur J Orthod 2007;29(5):477-81. https://doi.org/10.1093/ejo/cjm050

9. Socransky SS, Haffajee AD. The bacterial etiology of destructive periodontal disease: current concepts. J Periodontol 1992;63(4 Suppl):322-31.

https://doi.org/10.1902/jop.1992.63.4s.322

10. Petti S, Barbato E, Simonetti D'Arca A. Effect of orthodontic therapy with fixed and removable appliances on oral microbiota: a six-month longitudinal study. New Microbiol 1997;20(1):55-62.

11. Atack NE, Sandy JR, Addy M. Periodontal and microbiological changes associated with the placement of orthodontic applian- 
ces. A review. J Periodontol 1996;67(2):78-85.

https://doi.org/10.1902/jop.1996.67.2.78

12. Marini I, Bortolotti F, Parenti SI, Gatto MR, Bonetti GA. Combined effects of repeated oral hygiene motivation and type of toothbrush on orthodontic patients: a blind randomized clinical trial. Angle Orthod 2014;84(5):896-901.

https://doi.org/10.2319/112113-856.1

13. Mulla Issa FHK, Mulla Issa ZHK, Rabah AF, Hu L. Periodontal parameters in adult patients with clear aligners orthodontics treatment versus three other types of brackets: a cross-sectional study. J Orthod Sci 2020;9:4.

https://doi.org/10.4103/jos.JOS_54_17

14. Krieger E, Drechsler T, Schmidtmann I, Jacobs C, Haag S, Wehrbein H. Apical root resorption during orthodontic treatment with aligners? A retrospective radiometric study. Head Face Med 2013;9:21.

https://doi.org/10.1186/1746-160X-9-21

15. Miethke R-R, Brauner K. A Comparison of the periodontal health of patients during treatment with the Invisalign system and with fixed lingual appliances. J Orofac Orthop 2007;68(3):223-31.

https://doi.org/10.1007/s00056-007-0655-8

16. Miethke R-R, Vogt S. A comparison of the periodontal health of patients during treatment with the Invisalign system and with fixed orthodontic appliances. J Orofac Orthop 2005;66(3):219-29. https://doi.org/10.1007/s00056-005-0436-1

17. Madariaga ACP, Bucci R, Rongo R, Simeon V, D'Antò V, Valletta R. Impact of fixed orthodontic appliance and clear aligners on the periodontal health: a prospective clinical study. Dent J (Basel) 2020;8(1).

https://doi.org/10.3390/dj8010004

18. Chhibber A, Agarwal S, Yadav S, Kuo C-L, Upadhyay M. Which orthodontic appliance is best for oral hygiene? A randomized clinical trial. Am J Orthod Dentofacial Orthop 2018;153(2):175-83.

https://doi.org/10.1016/j.ajodo.2017.10.009

19. Levrini L, Mangano A, Montanari P, Margherini S, Caprioglio A, Abbate GM. Periodontal health status in patients treated with the Invisalign( $\left({ }^{\circledR}\right)$ system and fixed orthodontic appliances: a 3 months clinical and microbiological evaluation. Eur J Dent 2015;9(3):404-10.

https://doi.org/10.4103/1305-7456.163218

20. Karkhanechi M, Chow D, Sipkin J, Sherman D, Boylan RJ, Norman RG, et al. Periodontal status of adult patients treated with fixed buccal appliances and removable aligners over one year of active orthodontic therapy. Angle Orthod 2013;83(1):146-51. https://doi.org/10.2319/031212-217.1

21. Rossini G, Parrini S, Castroflorio T, Deregibus A, Debernardi CL. Periodontal health during clear aligners treatment: a systematic review. Eur J Orthod 2015;37(5):539-43.

https://doi.org/10.1093/ejo/cju083
22. Addy M, Shaw WC, Hansford P, Hopkins M. The effect of orthodontic appliances on the distribution of Candida and plaque in adolescents. Br J Orthod 1982;9(3):158-63.

https://doi.org/10.1179/bjo.9.3.158

23. Türköz C, Canigür Bavbek N, Kale Varlik S, Akça G. Influence of thermoplastic retainers on Streptococcus mutans and Lactobacillus adhesion. Am J Orthod Dentofacial Orthop 2012;141(5):598-603.

https://doi.org/10.1016/j.ajodo.2011.11.021

24. Peng Y, Wu R, Qu W, Wu W, Chen J, Fang J, et al. Effect of visual method vs plaque disclosure in enhancing oral hygiene in adolescents and young adults: a single-blind randomized controlled trial. Am J Orthod Dentofacial Orthop 2014;145(3):280-6.

https://doi.org/10.1016/j.ajodo.2013.10.021

25. Ramsay DS. Patient compliance with oral hygiene regimens: a behavioural self-regulation analysis with implications for technology. Int Dent J 2000;Suppl Creating A Successful:304-11. https://doi.org/10.1111/j.1875-595X.2000.tb00580.x

\section{PERIODONTAL HEALTH STATUS IN PATIENTS TREATED WITH CLEAR ALIGNERS AND FIXED ORTHODONTIC APPLIANCES}

\section{K. Labutyte்}

Keywords: clear aligners, fixed orthodontic appliances, periodontal health, dental plaque, gingival health.

Summary

Fixed orthodontic appliances temporarily interfere with periodontal health of patients, as the fixed appliance complicates oral hygiene. The use of removable aligners in orthodontic therapy increased strongly during the last decade. Clear aligners are considered to facilitate better oral hygiene than traditional fixed orthodontic appliances. The aim of this study is to evaluate, systematize and analyze medical research found in the scientific literature comparing periodontal health status in patients receiving fixed orthodontic treatment with clear removable aligners. Six full-text studies were included in this review. Based on the results of selected studies, it can be stated that there are conflicting reports in the literature. Periodontal health is statistically significantly better when patients are treated with removable aligners compared with the patients treated with fixed orthodontic appliances or there is no significant differences among these two groups. High-quality randomized controlled trials with rigorous methodology and proper sample size are needed in order to increase the power of the studies for estimating the periodontal effects and make a conclusive recommendation.

Correspondence to: labutytek@gmail.com

Gauta 2021-04-18 